\title{
Fougerite a Natural Layered Double Hydroxide in Gley Soil: Habitus, Structure, and Some Properties
}

\author{
Fabienne Trolard and Guilhem Bourrié \\ Additional information is available at the end of the chapter
}

http://dx.doi.org/10.5772/50211

\section{Introduction}

In soils, the clay fraction defined by particles with a size less than $2 \mu \mathrm{m}$, contains numerous minerals, which have fascinated many people to determine their structure and study their properties in the environment. For example, very soon after the time of the discovery of the Bragg's rule and the development of X-ray diffraction since 1918, Tamm (1922) developed a chemical pre-treatment of the samples to separate the well crystallized clays from the "undefined mixture of Si, Fe, Al" contained in soils. Then in 1960 - 1980, a large community in the World has studied the well crystallized clay - minerals, such as kaolinite, nontronite, montmorillonite, vermiculite, bentonite... from mining deposits. It has established the structures, explained the negative charges of the layer in relationship with substitution of structural cations III by cations II in the layer, neutralized by interlayered cations. This kind of structures induced particular properties in soils such as cationic exchange capacity or swelling... In the 1990-years, a new family of phyllites appears, the Layered Double Hydroxides (LDHs), named "anionic clays", that has layered structure with an anionic exchange capacity and particular electrochemical and magnetic properties. Easily synthetized, LDHs are essentially studied in the laboratory for industrial applications.

In soils, the study of LDHs emerges, because these constituents well crystallized, have particle size often less than $500 \mathrm{~nm}$, develop a large reactivity with the soil solution and interfer with many biogeochemical cycles, e.g. Fe, $\mathrm{Si}, \mathrm{Al}, \mathrm{Mg}, \mathrm{Ca}, \mathrm{K}, \mathrm{N}$.... In soils, fougerite, is a $\mathrm{LDH}$, responsible for the blue-green colour of gleysols. It can be identified simply in the field by its colour that changes to ochre when in contact with oxygen from the atmosphere.

The purpose of this chapter is to expose some thermodynamic properties deduced from the study of the natural LDH, fougerite, and propose their extension to other LDHs. 


\section{The natural LDH: fougerite}

Fougerite (IMA 2003-057) is the natural green rust mineral responsible for the bluish to greenish colours expressing reductomorphic properties (Driessen et al. 2001, Annex 2, p.314). As early as in the original definition of gley by Vyssotskii (1905, [1999]), the colour of gley was considered as indicating the presence of Fe "protoxide", i.e. of ferrous oxide (s.l.). This colour has been ascribed to "green rust" by Taylor (1981). Green rusts are intermediate compounds in the corrosion of steel first evidenced by Girard and Chaudron (1935). The first evidence for green rust, as a natural mineral, was provided by Trolard et al. $(1996,1997)$. The mineral was identified in a gleysol developed on granite in Fougères (Brittany, France), from which the name fougerite was proposed. To determine the occurrence, the reactivity and the structure of fougerite, selective dissolution techniques, Mössbauer, Raman and EXAFS spectroscopies and thermodynamic modelling were used both on natural samples and synthesized compounds. The mineral was homologated by the International Mineralogical Association in 2004 (Trolard et al. 2007).

The originality of fougerite is that instead of the other LDHs, such as $\mathrm{Ca}-\mathrm{Al}(\mathrm{III})$ or $\mathrm{Ni}(\mathrm{II})$ $\mathrm{Al}(\mathrm{III}) \mathrm{LDH}, \mathrm{Fe}(\mathrm{II})$ and $\mathrm{Fe}(\mathrm{III})$ can exchange electrons in the layer between each other. Though it is generally a nano-mineral, it is however not poorly ordered, but well crystallized (trigonal system).

\subsection{Habitus}

Iron is the main biogeochemical marker of gleyey soils. To observe fougerite in soils, different conditions with regard to hydric variations, biological and biochemical processes must be simultaneously fulfilled. They are:

- $\quad$ an excess of water;

- moderate reductive conditions;

- temperature conditions favourable to microflora activity;

- the presence of chemical elements that are able to record more or less irreversibly the variations of aerobic or anaerobic conditions, named geochemical markers (Trolard et al., 1998).

Soil colour is closely related to the nature of iron oxides, more specifically to their degree of hydration and their amount (Vyssotskii, 1905[1999]; Taylor, 1981; Cornell and Schwertmann, 2003). Moderately reduced waterlogged soils are characterized by the blue-green colour, which turns into ochre when the soils are open to the outer atmosphere (Vyssotskii, 1905[1999]; Ponnamperuma et al., 1967). It has been often ascribed to the occurrence in the milieu of mixed Fe(II) - Fe(III) compounds with a likely structure of green rust (GR). This assumption has been formulated since the 1960s and largely discussed in the literature (e.g. reviews by Taylor, 1981 or Lewis, 1997).

\subsection{Structure}

Green rusts belong to the large group of LDH compounds (table 1). The LDH structure is built of stacked layers of edge-sharing metal octahedra containing divalent and trivalent metal ions 
separated by anions between the interlayer spaces. The range of composition of LDHs is very narrow and they differ mainly by the nature of the interlayer anion (Allada et al., 2002). The general structural formula can be expressed as $\left[\mathrm{Me}(I I)_{1-\mathrm{x}} \mathrm{Me}(\mathrm{III})_{\mathrm{x}}(\mathrm{OH})_{2}\right]\left[\mathrm{x} / \mathrm{n} \mathrm{A}^{-\mathrm{n}}, \mathrm{mH}_{2} \mathrm{O}\right]$, where, for example, $\mathrm{Me}(\mathrm{II})$ could be $\mathrm{Mg}(\mathrm{II}), \mathrm{Ni}(\mathrm{II}), \mathrm{Co}(\mathrm{II}), \mathrm{Zn}(\mathrm{II}), \mathrm{Mn}(\mathrm{II})$ and $\mathrm{Fe}(\mathrm{II})$ and $\mathrm{Me}(\mathrm{III})$ is $\mathrm{Al}(\mathrm{III})$, $\mathrm{Fe}(\mathrm{III})$ and $\mathrm{Cr}(\mathrm{III})$ (Sparks, 2003). As all sites of the layer [Me(II) $\left.)_{1-x} \mathrm{Me}(\mathrm{III})_{\times}(\mathrm{OH})_{2}\right]$ are occupied, this exhibits a net positive charge $x$ per formula unit, which is balanced by an equal negative charge from interlayer anions $\mathrm{A}^{-n}$, such as $\mathrm{Cl}^{-}, \mathrm{Br}^{-}, \mathrm{I}^{-}, \mathrm{NO}_{3}^{-}, \mathrm{OH}^{-}, \mathrm{ClO}_{4}^{-}$and $\mathrm{CO}_{3}{ }^{2-}$. Water molecules are present too in the interlayer (figure 1).
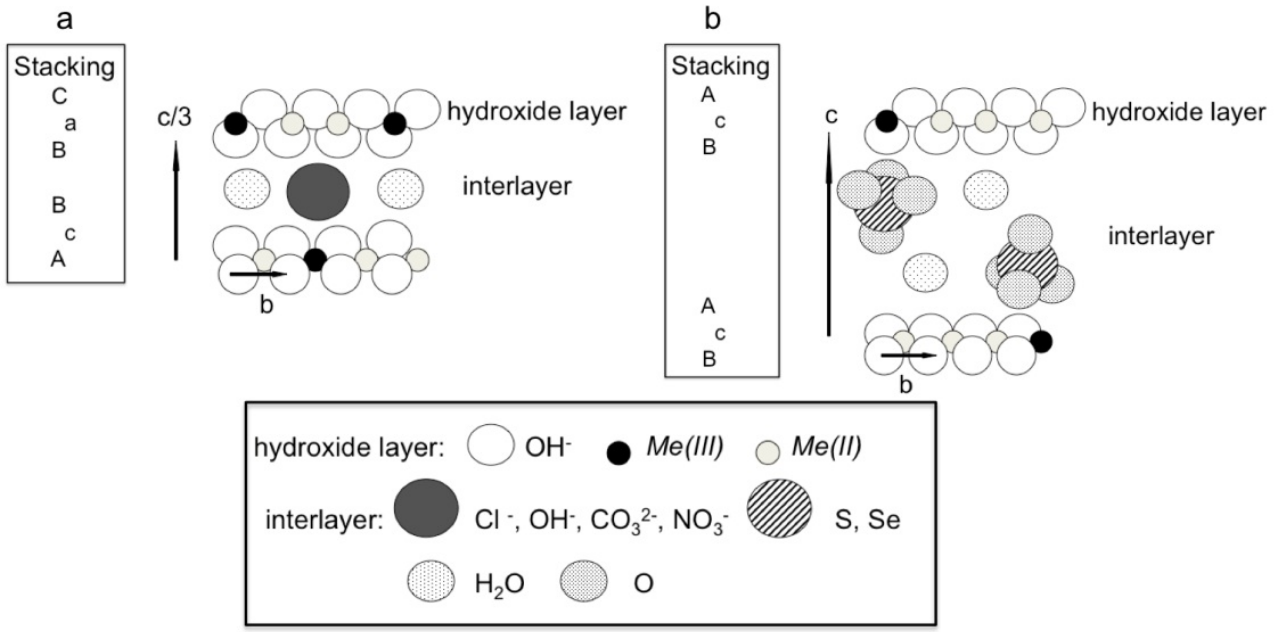

Figure 1. Stacking and structures of Green Rusts 1 (a) and 2 (b). Me(II) $=\mathrm{Fe}$ or $\mathrm{Mg}$ and $M e(I I I)=\mathrm{Fe}$ (from Trolard and Bourrié, 2008).

\begin{tabular}{|l|l|l|}
\hline mineral & Structural formula & Interlayer anion \\
\hline fougerite & {$\left[\mathrm{Mg}_{\mathrm{y}} \mathrm{Fe}^{\mathrm{II}}{ }_{1-\mathrm{x}} \mathrm{Fe}^{\mathrm{III}}{ }_{x}(\mathrm{OH})_{2}\right]\left[\mathrm{x} / \mathrm{n} \mathrm{A}^{-\mathrm{n}}, \mathrm{mH}_{2} \mathrm{O}\right]$} & Possible $: \mathrm{OH}^{-}, \mathrm{Cl}^{-}, \mathrm{CO}_{3}{ }^{2-} \ldots$ \\
\hline meixnerite & {$\left[\mathrm{Mg}_{6} \mathrm{Al}_{2}(\mathrm{OH})_{16}\right]\left[(\mathrm{OH})_{2}, 4 \mathrm{H}_{2} \mathrm{O}\right]$} & $\mathrm{OH}^{-}$ \\
\hline woodallite & {$\left[\mathrm{Mg}_{6} \mathrm{Cr}_{2}(\mathrm{OH})_{16}\right]\left[\left(\mathrm{Cl}^{-}\right)_{2}, 4 \mathrm{H}_{2} \mathrm{O}\right]$} & $\mathrm{Cl}^{-}$ \\
\hline iowaite & {$\left[\mathrm{Mg}_{4} \mathrm{Fe}^{\mathrm{III}}(\mathrm{OH})_{10}\right]\left[\left(\mathrm{Cl}^{-}\right), 2 \mathrm{H}_{2} \mathrm{O}\right]$} & $\mathrm{Cl}^{-}$ \\
\hline takovite & {$\left[\mathrm{Ni}_{6} \mathrm{Al}_{2}(\mathrm{OH})_{16}\right]\left[\left(\mathrm{CO}^{2-}, \mathrm{OH}^{-}\right), 4 \mathrm{H}_{2} \mathrm{O}\right]$} & $\mathrm{OH}^{-}, \mathrm{CO}_{3}{ }^{2-}$ \\
\hline hydrotalcite & {$\left[\mathrm{Mg}_{6} \mathrm{Al}_{2}(\mathrm{OH})_{16}\right]\left[\left(\mathrm{CO}_{3}{ }^{2-}\right), 4 \mathrm{H}_{2} \mathrm{O}\right]$} & $\mathrm{CO}_{3}{ }^{--}$ \\
\hline pyroaurite & {$\left[\mathrm{Mg}_{6} \mathrm{Fe}^{\mathrm{III}}(\mathrm{OH})_{16}\right]\left[\left(\mathrm{CO}_{3}{ }^{2-}\right), 4 \mathrm{H}_{2} \mathrm{O}\right]$} & $\mathrm{CO}_{3}{ }^{2-}$ \\
\hline
\end{tabular}

Table 1. Structural formula of some natural layered double hydroxides

Fougerite was first characterized by selective dissolution techniques, Mössbauer and Raman spectroscopies (Trolard et al., 1997). By EXAFS, the structure was confirmed, but it appeared that in addition to $\mathrm{Fe}, \mathrm{Mg}$ was present in the natural mineral (Refait et al. 2001).

The generic formula of synthetic green rusts is [Fe(II)1-x $\left.\mathrm{Fe}(\mathrm{III})_{x}(\mathrm{OH})_{2}\right]\left[\mathrm{x} / \mathrm{n} \mathrm{A}^{-\mathrm{n}}, \mathrm{mH}_{2} \mathrm{O}\right]$, where $x$ is in the range $[1 / 4-1 / 3]$. In the synthetic compounds, the interlayer anion is largely 
variable: $\mathrm{Cl}^{-}, \mathrm{Br}, \mathrm{I}^{-}, \mathrm{CO}_{3}{ }^{2-}, \mathrm{C}_{2} \mathrm{O}_{4}{ }^{2-}, \mathrm{SeO}_{4}{ }^{2-}, \mathrm{SO}_{3}{ }^{2-}, \mathrm{SO}_{4}{ }^{2-} \ldots$ With $\mathrm{Cl}^{-}, \mathrm{Br}, \mathrm{I}, \mathrm{CO}_{3}{ }^{2-}$ and $\mathrm{SO}_{3}{ }^{2-}$, that are small sized, spherical or planar anions, there is only one layer of water molecules in the interlayer, and the symmetry group is trigonal (GR1 structure) (Refait et al. 1998), while with $\mathrm{SeO}_{4}{ }^{2-}, \mathrm{SO}_{4}{ }^{2-}$, that are tetrahedral, there are two layers of water molecule, and the layer stacking is different (GR2 structure) (Simon et al. 2003). Green rusts can be easily synthesized in the laboratory (Murad, 1990), form by oxidation of Fe(II) in solution (Lewis, 1997), by partial oxidation of $\mathrm{Fe}(\mathrm{OH})_{2}$ (Génin et al. 1994) or by bacterial oxidation of $\mathrm{Fe}(\mathrm{III})$ oxides (Fredrickson et al. 1998).

As smectites can accommodate different cations in the interlayer, fougerite, green rusts and other LDHs can accommodate different anions. Indeed, natural minerals have been described with the same structure, in which $\mathrm{OH}^{-}, \mathrm{Cl}^{-}, \mathrm{CO}_{3}{ }^{2-}$ are the interlayered anions (figure 1). In Fougères, the most likely anion is $\mathrm{OH}^{-}$, as evidenced by considering soil/solution equilibria (Feder et al., 2005) and by XRD decomposition (Trolard and Bourrié, 2008). In other environments, $\mathrm{Cl}^{-}$or $\mathrm{CO}_{3}{ }^{2-}$ could be present too with a GR1 structure, and $\mathrm{SO}_{4}{ }^{2-}$ with a GR2 structure, but this was not yet found in the field.

\subsection{Some properties}

\subsubsection{Ionic exchange capacity}

Ion exchange involves electrostatic interactions between a counter-ion in the boundary layer between the solution and a charged particle surface and counter-ions in a diffuse cloud around the charged particle. It is usually a rapid, diffusion - controlled, reversible, stoichiometric reaction, and, in most cases, there is some selectivity of one ion over another by the exchanging surface (Sparks, 2003).

Ionic exchange capacity can be studied on bulk soil sample by measuring CEC (cationic Exchange Capacity) or AEC (Anionic Exchange Capacity). In 1:1 clay minerals, such as kaolinite, in metal oxides, amorphous materials and organic matter, ion exchange is due to surface sites that dissociate (Lewis acid, carboxylic or phenolic moieties), so that the net electric charge is $\mathrm{pH}$ dependent (Stumm, 1987; Sposito, 1989). In 2:1 clay minerals, in addition to Lewis acid sites, there exist isomorphic substitutions of different charge ions in the lattice, so that the net charge is the sum of a constant charge defect, always negative, and a $\mathrm{pH}$ dependent charge. The net resulting charge is negative, and is compensated by interlayer cations, more or less hydrated. The magnitude of CEC in soils is usually larger than AEC, but highly weathered soils in acidic environment can exhibit a substantial AEC.

As 2:1 clay minerals, LDHs contain constant positive charge due to the presence of both divalent and trivalent metals in the octahedral layer, and both external and internal exchanges sites, but the net resulting charge is positive, and the interlayer ions are anions. This is the basis of their designation as "anionic clays", though strictly speaking, LDHs are not clay minerals, as they are not phyllosilicates. Anions present in the interlayer sheet can be exchanged.

The property of exchange is often used to obtain some synthetic compounds that cannot be precipitated directly. This is the case for green rust with interlayer $\mathrm{CO}_{3}{ }^{2-}$ or $\mathrm{C}_{2} \mathrm{O}_{4}{ }^{2-}$, because presence of carbonate or oxalate in the initial solution inhibits the formation of $\mathrm{Fe}(\mathrm{OH})_{2}$ 
sheets, which is the first step to build up green rusts by precipitation. These green rusts are then obtained by exchanging the $\mathrm{SO}_{4}{ }^{2-}$ from a sulphate - green rust with $\mathrm{CO}_{3}{ }^{2-}$ or $\mathrm{C}_{2} \mathrm{O}_{4}{ }^{2-}$ (Drissi et al., 1994; Refait et al., 1998).

Much more basically, the properties of cationic or anionic exchange of clays and LDHs in soils contribute to the capacity of these soils to retain or release ions in a form available for plant uptake and contribute then to the supply of nutrients for plant growth. For example, this is the case for $\mathrm{Ca}^{2+}, \mathrm{Mg}^{2+}$ or $\mathrm{K}^{+}$from clays and $\mathrm{NO}_{3}{ }^{-}$or $\mathrm{SO}_{4}{ }^{2-}$ from $\mathrm{LDHs}$.

\subsubsection{Redox reactivity}

Redox reactivity is a particular property of Fe-LDH (green rust) and fougerite due to possible transition from ferric and ferrous state inside the hydroxide sheets. Thus two kinds of reactions can be observed: one affects only the hydroxide sheets and the second interacts with the interlayer anion.

The redox reactivity of the hydroxide sheets determines the stability and the transformation of Fe-LDH in other minerals. Concerning the stability, Refait et al. (2001) showed that in a same layer each $\mathrm{Fe}^{3+}$ ion must be surrounded only by bivalent, either $\mathrm{Fe}^{2+}$ ions or $\mathrm{Mg}^{2+}$ ions for the natural mineral fougerite. This is due to the fact that if the $\mathrm{Fe}^{\mathrm{III}} / \mathrm{Fe}$ total is up to $1 / 3$, the electrostatic repulsion of two neighbouring $\mathrm{Fe}^{3+}$ induces an oxolation reaction and the formation of $\mathrm{Fe}-\mathrm{O}-\mathrm{Fe}$ bonds. In the laboratory, this reaction permits to obtain a range of intermediate compounds between green-rusts and well crystallized $\mathrm{Fe}^{\mathrm{III}}$ - oxides such as lepidocrocite, goethite or hematite (e.g. Schwertmann and Fechter, 1994; Lewis, 1997). The final products depend on the kinetics of oxidation and the nature of the interlayer anion. In the field, in situ Mössbauer spectra can be obtained every two days and at different depths (Feder et al., 2005). The results show that $\mathrm{Fe}^{\mathrm{III}} / \mathrm{Fe}_{\text {total }}$ ratio changes with the dynamics of $\mathrm{pH}$ and Eh in the soil solution of the waterlogged soils, indicating that the proportion of $\mathrm{Fe}^{\mathrm{II}}$ and $\mathrm{Fe}^{\mathrm{III}}$ in the mineral changes with time and depth (figure 2).

Other works underlined that oxidation of Fe(II) from GRs was the most relevant abiotic reaction of reduction pathway in natural environments, soils and sediments. This is the case for reduction of selenate $\mathrm{Se}(\mathrm{VI})$ into $\mathrm{Se}(0)$ or Se(-II) (Myneni et al., 1997), $\mathrm{Ag}(\mathrm{I}), \mathrm{Au}(\mathrm{III})$, $\mathrm{Cu}(\mathrm{II})$ and $\mathrm{Hg}(\mathrm{II})$, respectively into $\mathrm{Ag}(0), \mathrm{Au}(0), \mathrm{Cu}(0)$ and $\mathrm{Hg}(0)\left(\mathrm{O}^{\prime} \mathrm{Loughlin}\right.$ et al., 2003) or $\mathrm{Cr}(\mathrm{VI})$ into $\mathrm{Cr}(\mathrm{III})$ (Loyaux-Lawniczak et al., 2000).

The redox reactivity due to the interactions between the hydroxide sheets and the interlayer anion can induce reactions which are not able without the contribution of the particular position of electron donors and acceptors. For example, while in solution $\mathrm{NO}_{3}$ - cannot be reduced by $\mathrm{Fe}^{2+}$, Hansen et al. (2001) show that Fe-LDHs reduced stoichiometrically $\mathrm{NO}_{3}{ }^{-}$ into $\mathrm{NH}_{4}{ }^{+}$and the kinetics of the reaction depend on the type of the interlayer anion, the hydroxide layer charge and the relative content of $\mathrm{Fe}(\mathrm{II})$ in the hydroxide layers. But the reduction of $\mathrm{NO}_{3}{ }^{-}$into $\mathrm{NH}_{4}{ }^{+}$in one step as observed, requires a simultaneous transfer of 8 electrons from $\mathrm{Fe}^{2+}$ to $\mathrm{N}$. When $\mathrm{NO}_{3}{ }^{-}$is in interlayer position in a green rust, the hydroxide layer reacts by oxolation of $\mathrm{Fe}(\mathrm{II})-\mathrm{OH}-\mathrm{Fe}(\mathrm{II})$ bonds into $\mathrm{Fe}(\mathrm{III})-\mathrm{O}-\mathrm{Fe}(\mathrm{III})$ releasing $8 \mathrm{e}^{-}$ and $8 \mathrm{H}^{+}$(figure 3 ). The GR oxidizes into hematite or goethite. For $\mathrm{GR}\left(\mathrm{SO}_{4}\right)$, the half-reactions and net reaction can be written as follows: 

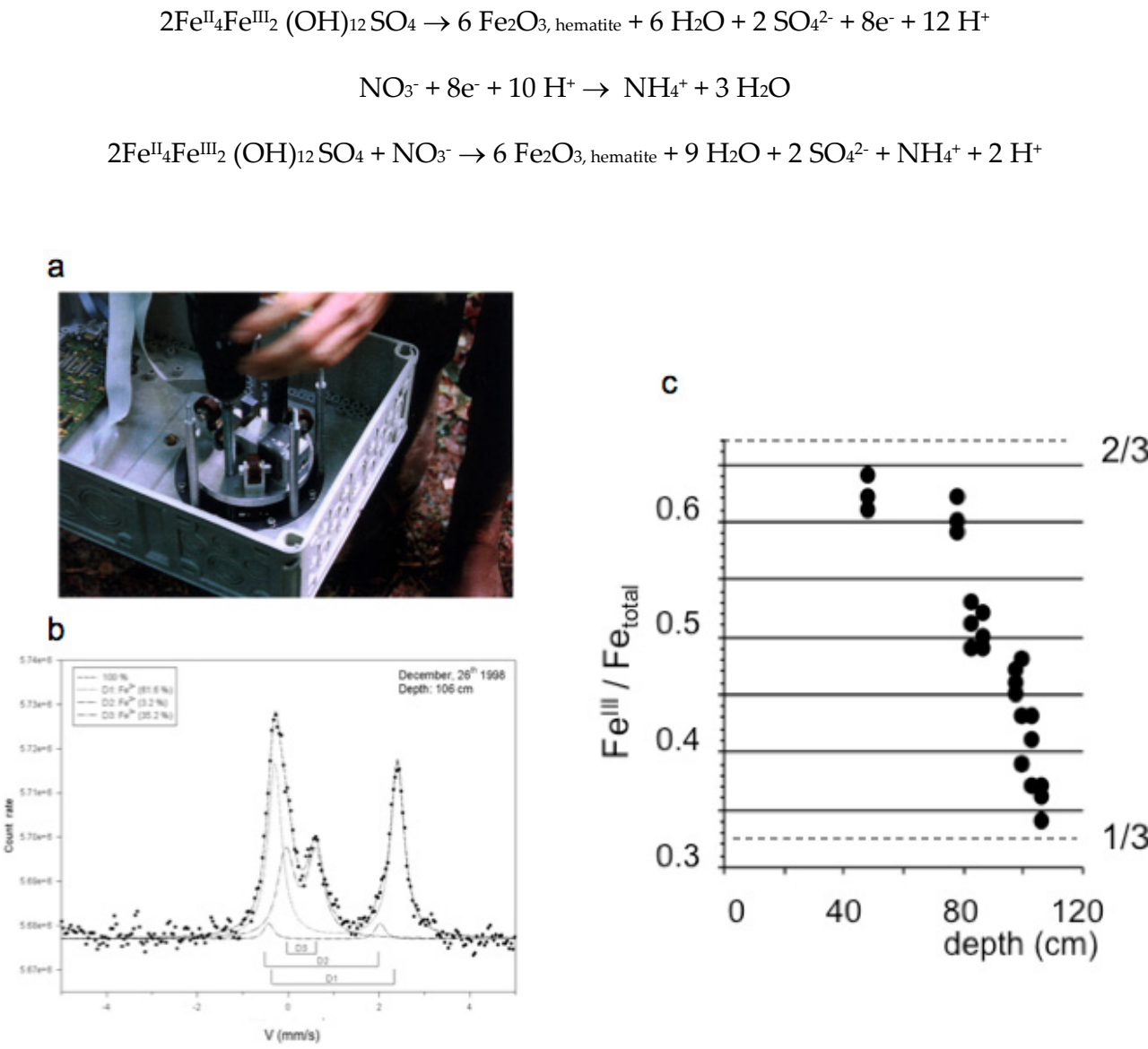

Figure 2. In situ Mössbauer monitoring in Fougères's soils (France): a. MIMOSII spectrometer used; $b$. Example of spectra obtained after two days of measurement in one depth; c. Variations of the ratio $\mathrm{Fe}^{\mathrm{III}} / \mathrm{Fe}$ total in soil with depth and time (from Feder et al., 2005).

\section{Thermodynamic modelling of stability of LDHs}

Thermodynamic properties of minerals mainly depend on the chemical composition of the mineral, and at a lesser degree on its structure. Evidence for this is the fact that nesosilicates include very soluble compounds such as olivine and quasi-insoluble minerals, e.g. zircon. Considering isostructural compounds, thermodynamic properties can thus be related with a suitable parameter depending on the chemical properties of ions. As the interaction between layer and interlayer is mainly electrostatic, we proposed to consider the electronegativity of the ion (Bourrié et al., 2004). Jolivet (1994) developed a partial charge model based upon Allred and Rochow's electronegativity scale. 

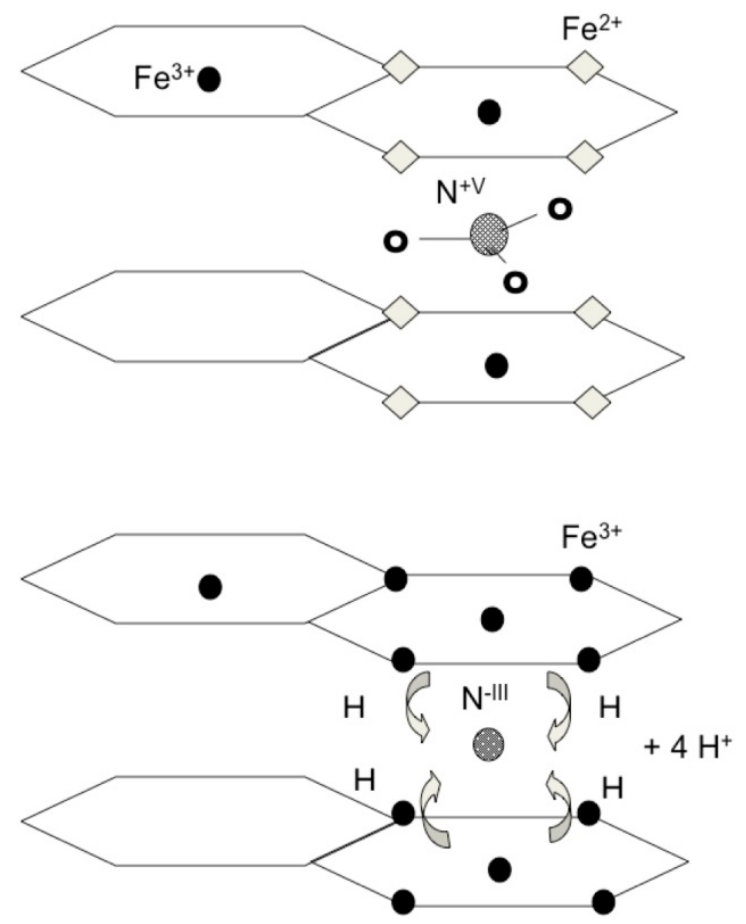

Figure 3. Reaction mechanism during the reduction of the interlayer $\mathrm{NO}_{3}{ }^{-}$with $\mathrm{Fe}^{\mathrm{II}}$ from hydroxide sheets in fougerite

\subsection{Thermodynamic data}

To develop thermodynamic modelling, the first difficulty is to obtain a homogeneous data base. Tables 2 and 3 contain the reference data that are used for all thermodynamic calculations presented here.

\subsection{Allred - Rochow electronegativity: A predictive parameter of the stability of hydroxides, oxyhydroxides and green rusts}

The Allred - Rochow electronegativity scale is based upon the interaction energies between one molecule or one ion and its electrons (Allred and Rochow, 1958). It is a function of bulk charge $\mathrm{Z}$ of this molecule or ion.

$$
\chi=(\partial \mathbf{E} / \partial \mathbf{N})
$$

where $\mathbf{E}$ is the energy of the molecule or ion and $\mathbf{N}$ the number of electrons.

The electronegativities of the elements, $\chi_{i}{ }^{*}$ are derived from the electronic affinity and first ionization energy of the element and are independent of $\mathrm{P}$ and $\mathrm{T}$. Following the partial charge model, developed by Jolivet (1994), the electronegativity of any molecule or ion can 


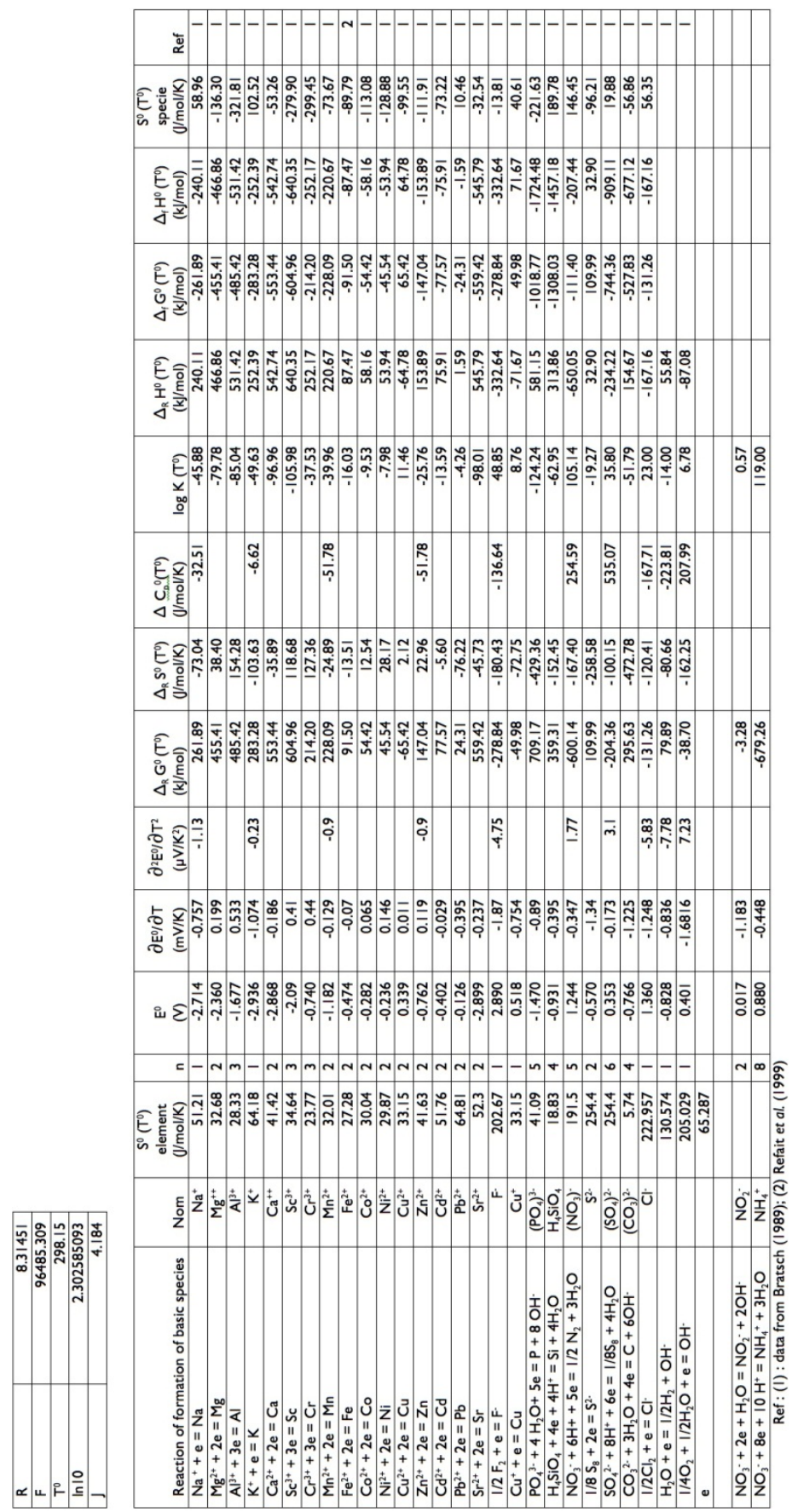

Table 2. Thermodynamical data used for calculation 


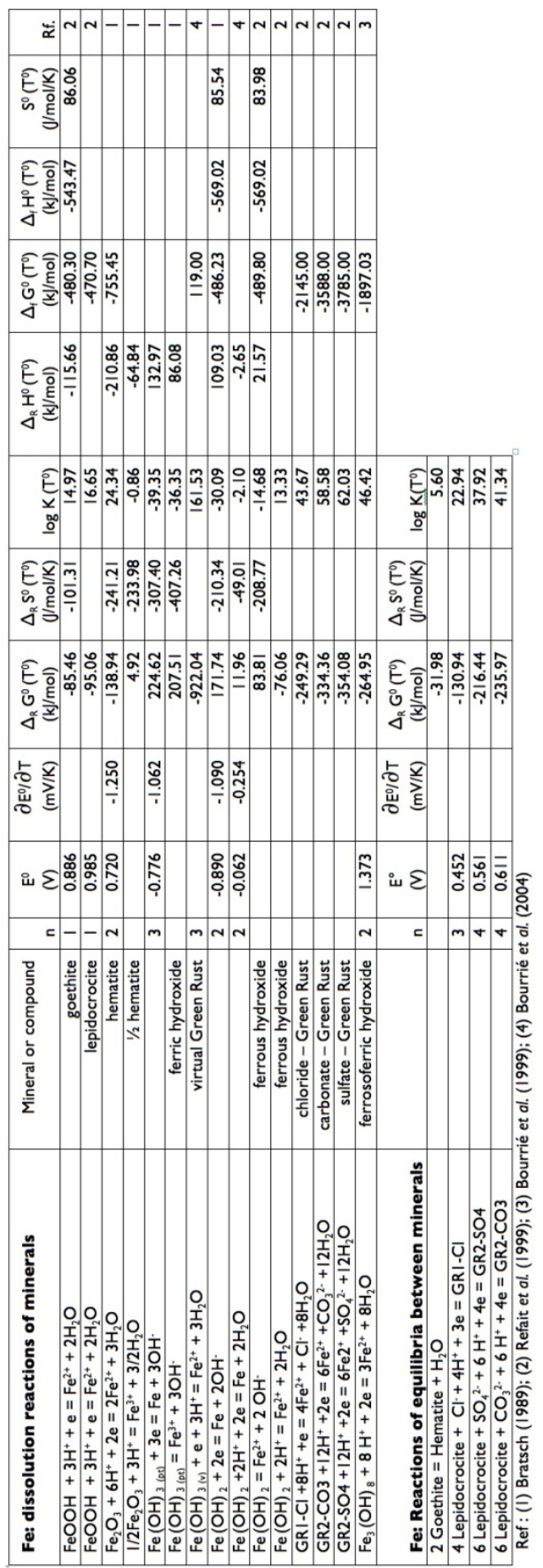

Table 3. Thermodynamical data used for calculation (suite) 
be computed from the stoichiometric formula, the electronegativities of the chemical elements, $\chi_{i}^{*}$ and the net electric charge of the ion. The relationship is given by the following equation:

$$
\chi=\frac{\sum_{i} v_{\mathrm{i}}\left(\chi_{\mathrm{i}}^{*}\right)^{1 / 2}+1.36 \mathrm{Z}}{\sum_{i} v_{\mathrm{i}}\left[1 /\left(\chi_{\mathrm{i}}^{*}\right)^{1 / 2}\right]}
$$

where $\mathrm{Z}$ is the global electrical charge of the molecule or ion, and the summation is carried upon all elements of the molecule or ion.

The electronegativity of any molecule or ion can thus be calculated. It is a microscopic term with the dimension of an energy. For example, to calculate the electronegativity of the hydroxyl group $\mathrm{OH}^{-}$, we used the electronegativity of oxygen and hydrogen $\chi^{*}(\mathrm{O})=3.5$ and $\chi^{*}(\mathrm{H})=2.1$, respectively and the charge of the anion is $\mathrm{Z}=-1$; thus the electronegativity of the hydroxyl group, $\mathrm{OH}^{-}$, is obtained as $\chi\left(\mathrm{OH}^{-}\right)=1$.6. In this way, with $\chi_{\mathrm{i}}^{*}=2.5$ for $\mathrm{C}, 2.83$ for $\mathrm{Cl}$ and 2.48 for $\mathrm{S}$ (Jolivet, 1994), the values obtained for the anions are $\chi\left(\mathrm{Cl}^{-}\right)=0.5421$, $\chi\left(\mathrm{CO}_{3}{ }^{2-}\right)=2.007$ and $\chi\left(\mathrm{SO}_{4}{ }^{2-}\right)=2.2856$ (Trolard and Bourrié, 2008). Table 4 summarizes the values of Allred-Rochow electronegativities of some chemical elements, anions and cations used in calculations.

\begin{tabular}{|l|c|l|c|}
\hline element & $\chi_{i}{ }^{*}$ & ion & $\chi_{i}$ \\
\hline $\mathrm{H}$ & 2.10 & $\mathrm{Cl}^{-}$ & 0.54 \\
\hline $\mathrm{C}$ & 2.50 & $\mathrm{OH}^{-}$ & 1.60 \\
\hline $\mathrm{N}$ & 3.07 & $\mathrm{SO}_{4}{ }^{2-}$ & 1.86 \\
\hline $\mathrm{O}$ & 3.50 & $\mathrm{CO}^{2-}$ & 2.00 \\
\hline $\mathrm{Mg}$ & 1.29 & $\mathrm{C}_{2}{ }^{2-}$ & 2.33 \\
\hline $\mathrm{Al}$ & 1.47 & $\mathrm{NO}^{2-}$ & 2.76 \\
\hline $\mathrm{Si}$ & 1.74 & $\mathrm{H}_{3} \mathrm{SiO}^{-}$ & 2.37 \\
\hline $\mathrm{S}$ & 2.48 & $\mathrm{Mn}^{2+}$ & 5.10 \\
\hline $\mathrm{Cl}$ & 2.83 & $\mathrm{Fe}^{2+}$ & 5.29 \\
\hline $\mathrm{Cr}$ & 1.59 & $\mathrm{Co}^{2+}$ & 5.35 \\
\hline $\mathrm{Mn}$ & 1.63 & $\mathrm{Ni}^{2+}$ & 5.45 \\
\hline $\mathrm{Fe}$ & 1.72 & $\mathrm{Cu}^{2+}$ & 5.35 \\
\hline $\mathrm{Co}$ & 1.75 & $\mathrm{Zn}^{2+}$ & 5.16 \\
\hline $\mathrm{Ni}$ & 1.80 & $\mathrm{Al}^{3+}$ & 6.42 \\
\hline $\mathrm{Cu}$ & 1.75 & $\mathrm{Cr}^{3+}$ & 6.73 \\
\hline $\mathrm{Zn}$ & 1.66 & $\mathrm{Fe}^{3+}$ & 7.07 \\
\hline & & $\mathrm{Co}^{3+}$ & 7.15 \\
\hline & & $\mathrm{Ni}^{3+}$ & 7.27 \\
\hline
\end{tabular}

Table 4. Allred-Rochow electronegativity values of some elements (from Jolivet, 1994) and ions (this work). 
The Gibbs free energy, i.e. $\Delta \mathrm{f} \mathrm{G}^{0}$, and the enthalpy of formation, i.e. $\Delta_{\mathrm{f}} \mathrm{H}^{0}$, of minerals or solid compounds are the main terms of macroscopic energy of interest. They can be obtained by the following semi-empirical equations:

$$
\Delta_{\mathrm{f}} \mathrm{H}^{0}(\mathrm{i})-\Delta_{\mathrm{f}} \mathrm{H}^{0}(\mathrm{j})=F[\chi(\mathrm{i})-\chi(\mathrm{j})]
$$

or

$$
\Delta \mathrm{f}^{0}(\mathrm{i})-\Delta_{\mathrm{f}} \mathrm{G}^{0}(\mathrm{j})=F[\chi(\mathrm{i})-\chi(\mathrm{j})]
$$

where $F$ is the Faraday constant, i.e. $F=N e$ where $N$ is the Avogadro Number et $e$ the electron charge, $i$ and $j$ indexing the ions exchanged or substituted in isostructural compounds. The multiplication by $F$ transforms the energy from the microscopic (atomic) scale to the macroscopic (molar) scale.

\subsubsection{Hydroxides and oxyhydroxides}

Thermodynamic data used here were taken from Bratsch (1989). The enthalpies of formation of hydroxides, with the general formula: $\mathrm{Me}\left(\mathrm{II}(\mathrm{OH})_{2}\right.$, and oxyhydroxides, $\mathrm{Me} e^{\mathrm{II}} \mathrm{OOH}$, are plotted versus Allred-Rochow electronegativities of bivalent and trivalent metals respectively (figure 4). The considered divalent metals are: $\mathrm{Mn}, \mathrm{Zn}, \mathrm{Fe}, \mathrm{Co}, \mathrm{Ni}, \mathrm{Cu}$ and the trivalent metals are: $\mathrm{Al}, \mathrm{Cr}$, $\mathrm{Fe}, \mathrm{Ni}$ and $\mathrm{Co}$. Linear correlations are observed both for these hydroxides and oxyhydroxides.

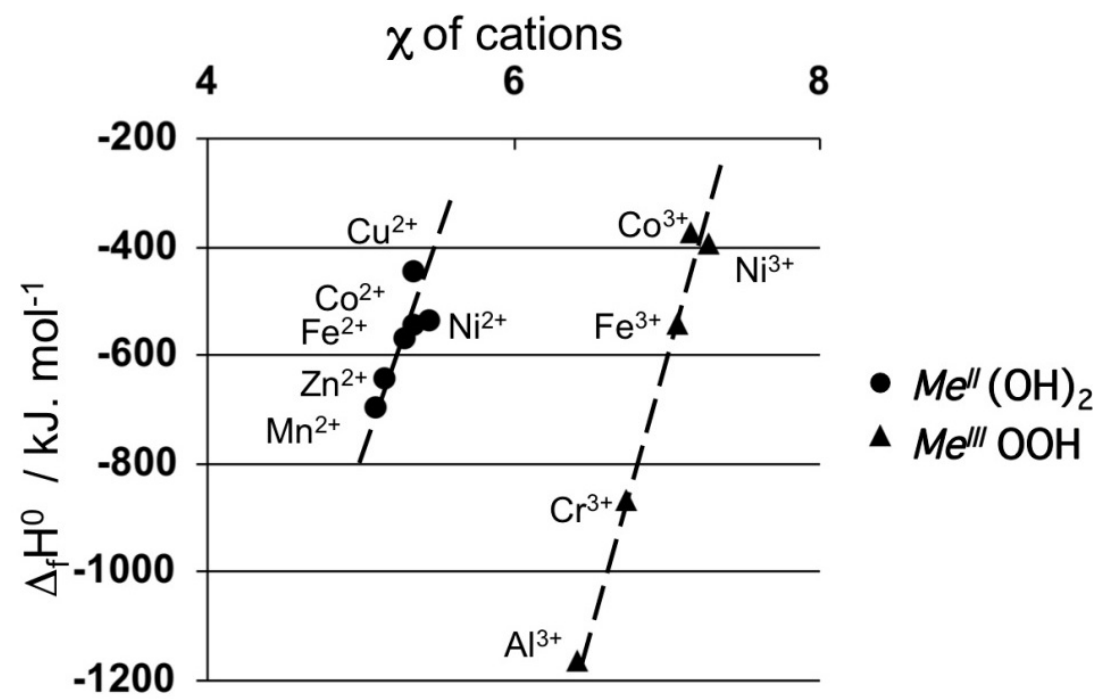

Figure 4. Relationship between enthalpies of formation of $\mathrm{Me}$ (II)-hydroxides and $\mathrm{Me}(\mathrm{III})$ oxyhydroxides and electronegativity of divalent and trivalent cations respectively.

\subsubsection{Green rusts}

The Gibbs free energies of formation of synthetic green rusts are plotted versus Allred Rochow electronegativities of the interlayer anions (figure 5). The value of the Gibbs free 
energy of $\mathrm{Fe}(\mathrm{OH})_{2}$ is plotted at $\chi=0$, as the interlayer is empty. Both Gibbs free energies and electronegativities are normalized to 2 structural $\mathrm{OH}$ per mole formula, i.e. for one third of the unit cell of a brucitic layer $\mathrm{Mg}_{3}(\mathrm{OH})_{6}$ or $\mathrm{Fe}^{\mathrm{II}_{3}}(\mathrm{OH})_{6}$. A linear correlation is obtained for Green Rusts, from which the value of the Gibbs free energy for fougerite is derived, using $\chi$ $=1.6$ for $\mathrm{OH}^{-}$. This relationship has as consequence to show a differential selectivity between the different anions, following the sequence $\mathrm{Cl}^{-}<\mathrm{OH}^{-}<\mathrm{CO}_{3}{ }^{2-}<\mathrm{SO}_{4}{ }^{2-}$ increasing the stability of the structure and permitting the interlayer anion exchanges.

\section{$\chi$ of interlayer anion}

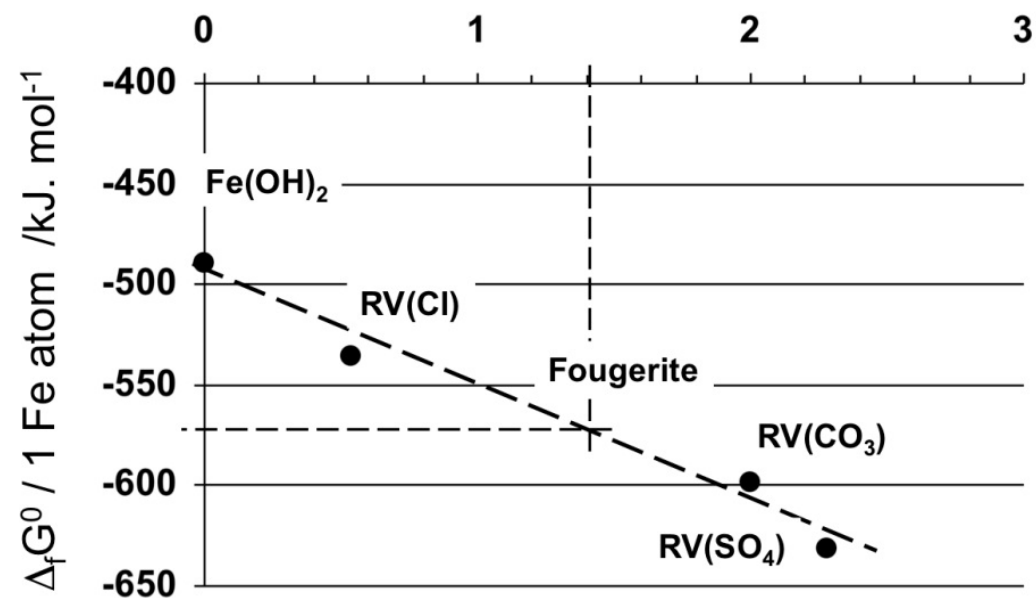

Figure 5. Relationship between Gibbs free energies of formation of green rusts (Fe LDHs) and the electronegativity of the interlayer anion.

\subsection{Modeling of the LDH thermodynamic stability in presence of Si: a possible pathway to clay mineral formation.}

\subsubsection{Experimental data used}

The study of the thermodynamic stability of $\mathrm{LDH}$ in presence of $\mathrm{Si}$ is based on experimental data obtained on hydrotalcite - like compounds with the general formula $\left[\mathrm{Me}(\mathrm{II})_{1-\mathrm{x}} \mathrm{Al} \times(\mathrm{OH})_{2}\right]$. $\left[\mathrm{x} / \mathrm{n} \mathrm{A}^{-\mathrm{n}}, \mathrm{mH}_{2} \mathrm{O}\right]$ with $(0.2<\mathrm{x}<0.4)$ and $\mathrm{Me}(I I)=\mathrm{Ni}$ (Allada et al., 2002; 2006).

The range of composition of LDHs is very narrow and they differ, in the first order, mainly by the nature of the interlayer anion (Allada et al., 2002, Bourrié et al., 2004).

Enthalpies of formation of Ni-Al LDHs were taken from Peltier et al. (2006) (table 5).

\subsubsection{Results of the calculation}

Same as Green Rust above, the value of the enthalpy of formation of $\mathrm{Ni}(\mathrm{OH})_{2}$ is plotted at $\chi$ $=0$, as the interlayer is empty. A large decrease is observed when LDHs form and figure 6 shows that the enthalpies of formation of synthetic Ni-Al LDHs are very close to each other 
when the compensating anion is sulphate, carbonate or nitrate. The enthalpy of LDHs when silicate anion is present in addition to carbonate shows a more negative value.

\begin{tabular}{|c|c|c|c|c|c|c|c|c|c|c|}
\hline \multirow[b]{2}{*}{ compounds } & \multicolumn{8}{|c|}{ Value of the stoichiometric coefficients in the Ni-Al LDHs } & \multirow{2}{*}{$\begin{array}{c}\Delta \mathrm{f} \mathrm{H}^{0} \\
/ \mathrm{kJ} \cdot \mathrm{mol}^{-1}\end{array}$} & \multirow{2}{*}{$\begin{array}{c}\Delta \mathrm{f} \mathrm{G}^{0} \\
/ \mathrm{kJ} \cdot \mathrm{mol}^{-1}\end{array}$} \\
\hline & $\mathrm{Ni}$ & $\mathrm{Al}$ & $\mathrm{NO}_{3}^{-}$ & $\mathrm{CO}_{3}^{2-}$ & $\mathrm{SO}_{4}^{2-}$ & $\mathrm{H}_{3} \mathrm{SiO}_{4}^{-}$ & $\mathrm{OH}$ & $\mathrm{H}_{2} \mathrm{O}$ & & \\
\hline NO3-2 & 0.65 & 0.35 & 0.21 & 0.07 & 0 & 0 & 2 & 0.42 & -942.41 & -807.60 \\
\hline $\mathrm{NO} 3-\mathrm{H}$ & 0.66 & 0.34 & 0.24 & 0.05 & 0 & 0 & 2 & 0.3 & -904.03 & -773.90 \\
\hline NO3-10 & 0.77 & 0.23 & 0.13 & 0.05 & 0 & 0 & 2 & 0.6 & -908.42 & -776.00 \\
\hline SO4-2 & 0.66 & 0.34 & 0 & 0.02 & 0.15 & 0 & 2 & 0.21 & -940.30 & -823.20 \\
\hline SO4-H & 0.65 & 0.35 & 0 & 0.025 & 0.15 & 0 & 2 & 0.22 & -957.52 & -839.40 \\
\hline SO4-10 & 0.72 & 0.28 & 0 & 0.02 & 0.12 & 0 & 2 & 0.43 & -952.78 & -829.30 \\
\hline $\mathrm{CO} 3-2$ & 0.64 & 0.36 & 0 & 0.18 & 0 & 0 & 2 & 0.46 & -987.30 & -862.00 \\
\hline CO3-H & 0.66 & 0.34 & 0 & 0.17 & 0 & 0 & 2 & 0.42 & -950.57 & -851.40 \\
\hline $\mathrm{CO} 3-5$ & 0.67 & 0.33 & 0 & 0.17 & 0 & 0 & 2 & 0.41 & -930.47 & -828.70 \\
\hline $\mathrm{CO} 3-\mathrm{Si}$ & 0.65 & 0.35 & 0 & 0.1 & 0 & 0.15 & 2 & 0.08 & -1132.27 & -925.40 \\
\hline $\mathrm{Ni}(\mathrm{OH})_{2}$ & 1 & 0 & 0 & 0 & 0 & 0 & 2 & 0 & -540.34 & -459.10 \\
\hline $\mathrm{Al}(\mathrm{OH})_{3}$ & 0 & 1 & 0 & 0 & 0 & 0 & 3 & 0 & -1293.00 & -1155.00 \\
\hline
\end{tabular}

Table 5. Enthalpies of formation and Gibbs free energies obtained by Peltier et al. (2006) on Ni-Al LDHs used in calculations

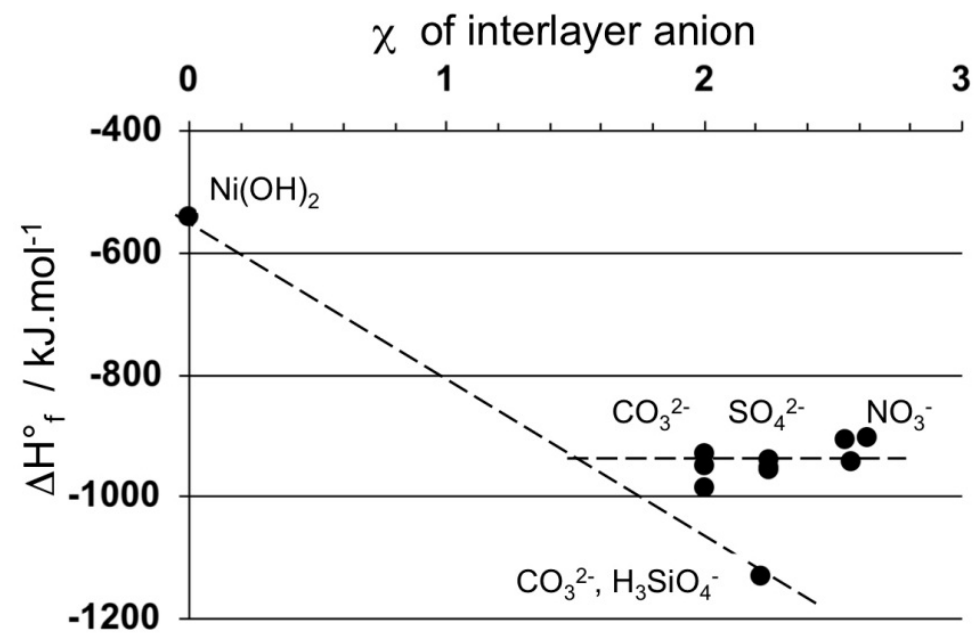

Figure 6. Relationship between enthalpies of formation of Ni-Al LDHs and average electronegativities of $\mathrm{A}^{-\mathrm{n}}$ anion.

As the composition of the layer is quasi-constant, i.e. $x \in[1 / 4 ; 1 / 3]$, the variation of the enthalpy formation can be written:

$$
\Delta_{\mathrm{f}} \mathrm{H}^{0}(\mathrm{LDH})=\Delta_{\mathrm{f}} \mathrm{H}^{0}{ }_{\text {(hydr. })}-x F \chi(\text { anion })+m \Delta_{\mathrm{f}} \mathrm{H}^{0}{ }_{\mathrm{w}, \mathrm{c}}
$$


where $m$ is the number of moles of water in the interlayer under a crystalline state, $x$ the electric charge of the hydroxide layer and $F$ the Faraday constant (cf. supra). The minus sign comes from the negative charge of the anion.

The quantity $\Delta_{\mathrm{f}} \mathrm{H}^{0}(\mathrm{LDH})+x F \chi($ anion) is plotted versus the number of moles of water molecules per mole formula (figure 7). Two groups appear distinctly: all LDHs without silicate anion in the interlayer, and mixed silicate-carbonate Ni/Al-LDHs.

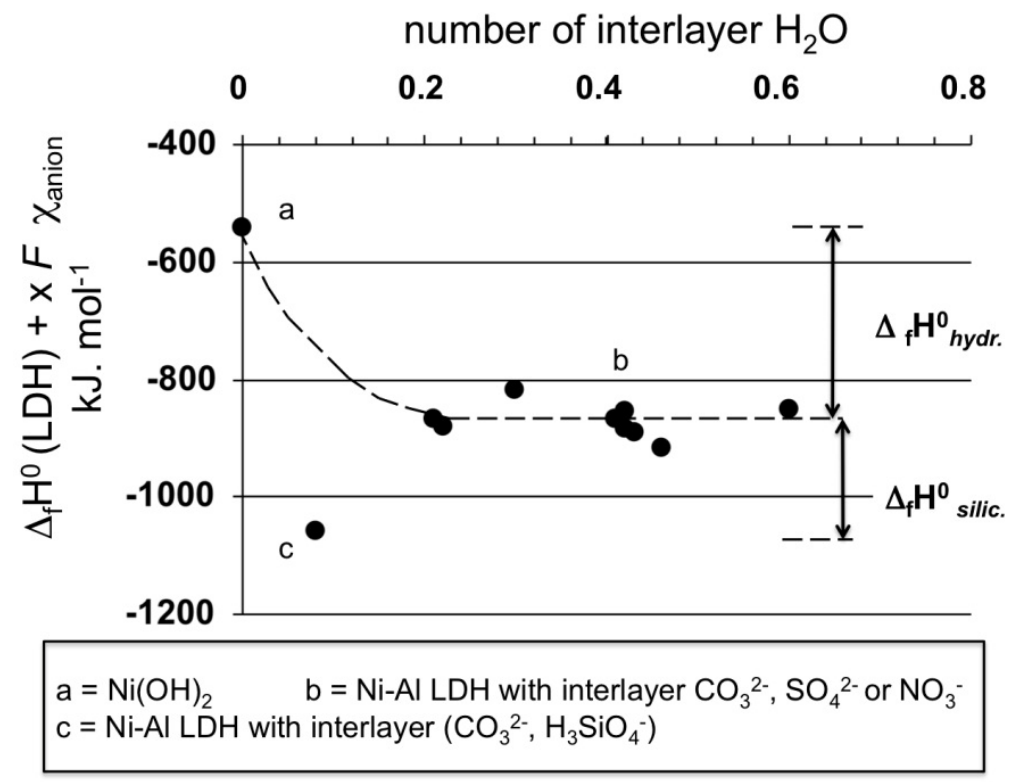

Figure 7. Relationship between enthalpies of formation of Ni-Al LDHs corrected from the contribution of electronegativities of $\mathrm{A}^{\mathrm{A}} \mathrm{n}$ anion and the number of moles of water in the interlayer.

The large variation of enthalpy from the pure $M e(I I)$ - hydroxide to the first stable LDHs can be ascribed to the opening and hydration of the interlayer as soon as the net charge of the layer is not zero, i.e. the enthalpy of hydration of the layers: $\Delta \mathrm{fH}^{0}$ hydr.. This explains the large deviation from ideality observed when modelling these compounds as solid solution (e.g. Bourrié et al., 2004 for Fe-LDHs or green rusts). As this term is large, the influence of the nature of the interlayer anion is masked. However, it would be interesting to check the influence of anions with larger electronegativities, such as $\mathrm{Cl}^{-}$.

The silica anion exerts a large influence by expelling water molecules. This does not lead to a reversal to more positive values of $\Delta_{\mathrm{f}} \mathrm{H}_{(\mathrm{LDH})}^{0}$, but instead to more negative. It can be ascribed to condensation of silicate anion with the LDH layer with elimination of water molecules, hence the nucleation of $\mathrm{Ni}(\mathrm{II})-\mathrm{Al}$ clay mineral by polymerization of silica within the interlayer following the anion exchange carbonate/silicate (Peltier et al., 2006).This implies that silica combines to the hydroxide sheets, as a first step towards new formation of phyllosilicate minerals. It is possible that the hydroxyl groups of the hydroxide sheets begin 
then condensate with hydroxyl groups of the silicate tetrahedra. This is not the case with sulphate, which give rise in green rusts to two monomolecular layers of water, instead of only one with planar anions.

\section{Conclusions}

Fougerite, as other layered double hydroxides (Sparks, 2003), plays an essential role in the formation of clay minerals, both phyllosilicates and iron hydroxides and oxides. They control both major elements, e.g. $\mathrm{Mg}$, Fe, and trace metals ( $\mathrm{Co}, \mathrm{Cr}, \mathrm{Mn}, \mathrm{Ni}$ and $\mathrm{Zn}$ ) in the environment.

Electronegativity of ions, computed following the model of partial charges by Jolivet (1994) is a suitable parameter to correlate macroscopic thermodynamic properties of isostructural compounds when interactions are mainly electrostatic. It is of special value for small sized natural minerals that cannot be isolated and purified, and to assess consistency between experimental data sets.

The introduction of silicate anion by anionic exchange in a LDHs structure leads to a reduction of the number of water molecules in the interlayer and increases the stability of lamellar double hydroxide. This transient structure can be considered as the first step towards the formation of a new clay mineral.

\section{Author details}

Fabienne Trolard and Guilhem Bourrié

INRA, UMR1114, Environnement Méditerranéen et Modélisation des Agro-hydrosystèmes, Avignon, France

UAPV, UMR1114, Environnement Méditerranéen et Modélisation des Agro-hydrosystèmes, Avignon, France

\section{References}

Allada R.K., Navrotsky A., Berbeco H.T. and Casey W.H. (2002) Thermochemistry and aqueous solubilities of hydrotalcite-like solids. Science, 296, 721-723.

Allada R.K., Peltier E., Navrotsky A., Casey W.H., Johnson C.A., Berbeco H.T. and Sparks D. (2006) Calorimetric determination of the enthalpies of formation of hydrotalcite -like solids and their use in the geochemical modeling of metals in natural waters. Clays \& Clay Minerals, 54, 4, 409-417.

Allred A.L. and Rochow E.G. (1958) A Scale of electronegativity based on electrostatic force. J. Inorganic \& Nuclear Chemistry, 5, 264-268.

Bratsch S.G. (1989) Standard electrode potentials and temperature coefficients in water at 298.15 K. J. of Physical Chemical Reference Data,18, 1-21. 
Bourrié G., Trolard F., Génin J.M.R., Jaffrezic A., Maître V. and Abdelmoula M. 1999. Iron control by equilibria between hydroxi-green rusts and solutions in hydromorphic soils. Geochimica et Cosmochimica Acta, 63, 3417-3427.

Bourrié G., Trolard F., Refait P. and Feder F. (2004) A solid solution model for Fe(II) - Fe(III) - $\mathrm{Mg}(\mathrm{II})$ green rusts and fougerite and estimation of their Gibbs free energies of formation. Clays \& Clay Minerals, 52, 382-394.

Cornell R.M. and Schwertmann U. (2003) The iron oxides. $2^{\text {nd }}$ edition. VCH, Weinheim, Germany.

Driessen P., Deckers J., Spaargaren O. and Nachtergale F. (2001) Lecture notes on the major soils of the world. World Soil Resources Report n94, FAO, Rome.

Drissi S.H., Refait P., and Génin J.M.R. (1994) The oxidation of $\mathrm{Fe}(\mathrm{OH})_{2}$ in the presence of carbonate ions: structure of carbonate green rust one. Hyperfine Interactions, 90, 395400.

Feder F., Trolard F., Klingelhöfer G. and Bourrié G. (2005) In situ Mössbauer spectroscopy Evidence for green rust (fougerite) in a gleysol and its mineralogical transformation with time and depth. Geochimica et Cosmochimica Acta, 69, 4463-4483.

Fredrickson J.K., Zachara J.M., Kennedy D.W., Dong H., Onstott T.C., Hinman N.W. and Li S.M. (1998) biogenic ion mineralization accompagnying the dissimilatory reduction of hydrous ferric oxide by a groundwater bacterium. Geochimica et Cosmochimica Acta, 62, 3239-3257.

Génin J.M.R., Olowe A.A., Resiak B., Confente M., Rollet-Benbouzid N., L'Haridon S. and Prieur D. (1994) Products obtained by mycrobially-induced corrosion of steel in a marine environment. Role of green rust two. Hyperfine Interactions, 93, 1807-1812.

Girard A. and Chaudron G. (1935) Sur la constitution de la rouille. Comptes Rendus de l'Académie des Sciences, Paris, 200, 127-129.

Hansen H.C.B., Gulberg S., Erbs M. and Koch C.B. (2001) Kinetics of nitrate reduction by green rusts: effects of interlayer anion and Fe(II): Fe(III) ratio. Applied Clay Science, 18, 81-91.

Jolivet J.P. (1994) De la solution à l'oxyde. Savoirs Actuels, Interéditions, CNRS, 387 pp.

Lewis L.W. (1997) Factors influencing the stability and properties of green rusts. In : soils and Environment (Auerswald K., Stanjek H., Bigham J.M. eds.), Adv. In GeoEcology, Catena Verlag, 30, 345-372.

Loyaux-Lawniczak S., Refait P., Ehrhardt J.J., Lecomte P., and Génin J.MR. (2000) Trapping of $\mathrm{Cr}$ by formation of ferrihydrite during the reduction of chromate ions by $\mathrm{Fe}(\mathrm{II})-\mathrm{Fe}(\mathrm{III})$ hydroxysalt green rusts. Environmental Science \& Technology, 34, 438-443.

Mineny S.C.B., Tokunaga T.K. and Brown G.E.J. (1997) Abiotic selenium redox transformation in the presence of Fe(II, III) oxides. Science, 278, 1106-1109.

Murad E. (1990) Application of 57Fe Mössbauer spectroscopy to problems in clay minerals and soil science: possibilities and limitations. Advances in Soil Science, 12, 125-157.

O'Loughlin E.J., Kelly S.D., Kemner K.M., Csencsits R. and Cook R.E. (2003) Reduction of $\mathrm{Ag}^{\mathrm{I}}, \mathrm{Au}^{\mathrm{III}}, \mathrm{Cu}^{\mathrm{II}}$ and $\mathrm{Hg}^{\mathrm{II}}$ by $\mathrm{Fe}^{\mathrm{II}} / \mathrm{Fe}^{\mathrm{III}}$ hydroxysulfate green rust. Chemosphere, 53, 437446. 
Peltier E., Allada R.K., Navrotsky A. and Sparks D.L. (2006) Nickel solubility and precipitation in soils: a thermodynamic study. Clays and Clay Minerals, 54, 153-164.

Ponnamperuma F.N., Tianco E.M. and Loy T. (1967) Redox equilibria in flooded soils: I. The iron hydroxide systems. Soil Science, 103, 374-382.

Refait P., Charton A. and Génin J.M.R. (1998) Identification composition, thermodynamic and structural properties of pyroaurite-like iron(II)-iron(III) hydroxy-oxalate green rust. European J. Solid State Inorganic Chemistry, 35, 655-666.

Refait P., Bon C., Simon L., Bourrié G., Trolard F., Bessière J. and Génin J.M.R. 1999. Chemical composition and Gibbs standard free energy of formation of $\mathrm{Fe}(\mathrm{II})-\mathrm{Fe}(\mathrm{III})$ hydroxysulphate green rust and Fe(II)hydroxide. Clay Minerals, 34, 499-510.

Refait P., Abdelmoula M., Trolard F., Génin J.M.R., Ehrhardt J.J. and Bourrié G. (2001) Mössbauer and XAS study of green rust mineral; the partial substitution of $\mathrm{Fe}^{2+}$ by $\mathrm{Mg}^{2+}$. American Mineralogist, 86, 731-739.

Schwertmann U. and Cornell R.M. (2003) Iron oxides in the laboratory. Preparation and Characterization. VCH edition, Weinheim.

Schwertmann U. and Fechter H. (1994) The formation of green rust and its transformation to lepidocrocite. Clay Minerals, 29, 87-92.

Sparks D. (2003) Environmental soil chemistry. 2e edition, Academic press, Elsevier Science (USA).

Sposito G. (1989) The surface chemistry of soils. Oxford Univ. Press, New York.

Stumm W. (1987) Aquatic surface chemistry, Wiley, New York.

Tamm O. (1922) Eine Method zur Bestimmung der organisches Komponenten des Gelcomplexes in Boden. Medd. Statens Skogsfösöksanstalt, 19, 385-404.

Taylor R.M. (1981) Color in soils and sediments. A review. In: International Clay conference 1981 (ed. H. van Olphen and F. Veniale), Developments in Sedimentology, 35, 749-761 (Elsevier, Amsterdam).

Trolard F., Abdelmoula M., Bourrié G., Humbert B. and Génin J.M.R. (1996) Mise en évidence d'un constituant de type "rouilles vertes" dans les sols hydromorphes Proposition de l'existence d'un nouveau minéral : "la fougérite". C.R. Académie des Sciences, Paris, 323(série IIa), 1015-1022.

Trolard F., Génin J.M.R., Abdelmoula M., Bourrié G., Humbert B. and Herbillon A.J. (1997) Identification of a green rust mineral in a reductomorphic soil by Mössbauer and Raman spectroscopies. Geochimica et Cosmochimica Acta, 61, 1107-1111.

Trolard F., Bourrié G., Soulier A., Maître V., Génin J.M.R. and Abdelmoula M. (1998) Dynamique de l'oxydo-réduction dans les zones humides. In: Agriculture intensive et qualité des eaux (C. Cheverry coord.), pp. 185-208. Collection Update, INRA publications, Paris.

Trolard F., Bourrié G., Abdelmoula M., Refait P. and Feder F. (2007) Fougerite, a new mineral of the pyroaurite-iowaite group: description and crystal structure, Clays and Clay Minerals, 28, 179-187.

Trolard F. and Bourrié G. (2008) Geochemistry of green rusts and fougerite: a reevaluation of Fe cycle in soils. Advances in Agronomy, 99, chap. 5, 227-287. 
Vyssotskii G.N. (1905, [1999]) Gley. Pochvovedeniye, 4, 291-327 [Gley. An abridged publication of Vyssotskii 1905 on the 257th anniversary of the Russian Academy of Sciences. Eurasian Soil Science, 32, 1063-1068]. 